\title{
Para-ethnography, Golf, and the Internet
}

How did ordinary, nonelite Africans in Johnny's neighborhood learn enough to "trick" with European gay men? I'm using "trick" here both in the gay sense of having sex with and the African sense of outwitting. I have already suggested the most recent part of the answer: the Internet. Indeed, sexual extraversion and the Internet were in many ways preadapted to one another. First of all, as often has been pointed out, the Internet expands the role of fantasy and possible deception. But, secondly, the Internet dramatically increases the possibilities for gaining cultural knowledge about others. The need for such knowledge is particularly great when the intent is to some degree to deceive ("con men have to be smart") and when the others in question are themselves members of an evolved and sometimes subterranean subculture.

In a felicitous phrase, Douglas Holms and George Marcus (2008) recently called the process of interpretation of cultural others on the part of everyday actors "para-ethnography." Anthropologists, then, are not the only ethnographers. This being so, 
anthropology as an endeavor can become a kind of ethnography of ethnographers in some situations. For social actors, action in the world increasingly takes place with an awareness of -indeed a cultural theory of-alternate cultural worlds.

The Internet hardly created para-ethnography in Atlantic Africa, but without doubt, it has recently expanded its reach and depth. As we have seen, centuries ago, the contact zone introduced other cultural worlds to Atlantic Africans-eventually in dramatically violent ways. The colonial administrations that resulted, at least in the Gold Coast (Ray 2015), began to attack the centuries-old relationships between European men and local women, not so much because of the mixed-race children they produced (who were absorbed into the African population), but because of the leverage that African "in-laws" had traditionally exercised over European "husbands." With African women off limits, and many fewer European women in the colonies than men, the colonial order began to create significantly homosocial spaces.

It would surely be a mistake to call colonialism a gay project, but colonies attracted northern European white men drawn to other men (T.E. Lawrence, Roger Casement, and E. M. Forster being perhaps the most famous). But para-ethnography in colonial contexts, at least for illiterate Africans, was highly delimited and almost entirely sustained by forms of face-to-face communication. For ordinary Africans, these took place in domestic spaces in which houseboys, cooks, and gardeners came into sustained contact with white men and sometimes white women (Stoler 20Io). And - critical to the case at hand - certain kinds of sports, like golf, offered yet another venue.

Golf as we know it seems to have begun in fifteenth-century Scotland, where it was played in the roughs along the seashore. 
At times, Scottish kings tried to suppress the game since, unlike archery; it held no military value for the state. By the nineteenth century, golf was an elite avocation in Great Britain and had spread to British trade depots and colonies.

The secret of the uniqueness of Johnny's neighborhood is, I believe, its location next to a colonial-era golf course. Let me consider what a cultural innovation in landscape a golf course instituted. Before, chiefs had given Africans access to land in order to plant their swidden fields and to graze their animals. African landscapes reflected the residue of these layered processes (which to Europeans always seemed visibly disordered). When the golf course was established in the 1930s, a fence was built around the perimeter, enclosing an area into which ordinary Africans could no longer go, much less graze their animals. Foreign species of trees were planted. Holes were laid out, and the grass was mowed. To Africans, this space must have "summarized" colonialism: a powerful white fantasy they could not understand and from which they were excluded.

But Johnny and Justice's village was to some degree the exception. European golfers required caddies, after all, and young boys from Johnny's neighborhood quickly took up this role. Indeed, they organized to keep out other boys, situated just a little farther away. Personalized relationships between older European golfers and young African caddies developed in which African boys left their school lessons when "their" Europeans showed up at the tee. By the time of colonial independence, boys from the ghetto had worked as caddies for Europeans for more than three decades-against a regional history on the Atlantic African coast that extended much farther back. In the eighteenth century, British slave traders had built a twohole golf course on Bunce Island, where they were "served by 
African caddies dressed in kilts especially woven in Glasgow" (R. Shaw 2002, 29).

For decades before the end of colonialism, then, boys from the village that became the ghetto accumulated and shared knowledge of white culture. It is perhaps no surprise that a few of the relationships between golfers and caddies turned sexual. I gathered stories of two instances, one from a man in his twenties, another from one approximately fifty. The latter recounted, with evident great pleasure, stories of a European flight steward in the I970s who blew a horn that played his airline's radio advertising jingle as a signal that he had arrived at the golf course. Hearing the jingle, the African young man knew to come to the course. The two not only played golf over the time of the steward's layover. They ate and drank and had sex in the steward's hotel room. Through support from the steward, the African young man eventually made his way to London, where he lived for a number of years, in relationships with British gay men. Through these experiences, he gained a kind of worldliness that was altogether unusual for men of his background. In 20I2, after his Belgian lover had died, he continued to live in Johnny's neighborhood during the week but visited his wife and children on the weekends in a nicer neighborhood not far away.

We can now begin to appreciate, I think, why fucking a white man had become erotic for some African men. The answer has little to do with our notions of sexuality. Fucking, I take it, is always associated with feelings of power. After colonialism, when African men penetrated white bodies, they also imaginatively reversed colonial interdictions that had excluded them from wider cosmopolitan worlds. And to the extent there was some ruse involved, the humor that resulted must have added to the pleasure. What I am suggesting is that the wider terrain 
of desire always slides into and inflects the erotic. At some point, these two realms become impossible to separate. In her study of black women and the pleasures of racialized pornography, Jennifer Nash (20I4a, 452) writes, "My understanding of pleasure is capacious - it is an understanding that includes, of course, erotic and sexual pleasure, but that also includes political pleasures, humorous pleasures, pleasures in transgressing, pleasures in making use of and then upending racial fictions."

Golf prepared the way for the Internet. Both golf and the Internet provided the same kind of window onto a wider, desirable world. As so-called romance scams, both straight and gay, became notorious in Atlantic Africa by the 2000s, many North American and European websites blocked posters with IP addresses from the region. But at least one European gay site did not, and it became the site of choice in Johnny's new neighborhood. On a more or less representative day at II:०० A.M. California time in 2014, almost 100,000 Europeans were signed on to the site-with about 30,000 Asians, 800 North Americans, I,००० Middle Easterners, and 1,700 Africans.

Given their peculiar postcolonial history, the men in Johnny and Justice's neighborhood knew how to appeal to European gay men. Stories about sex with European men had circulated for decades in the ghetto before the Internet arrived. When cheap secondhand computers in Internet cafes began to make their inroads, strikingly, a few men posted photographs that depicted themselves almost exactly as Mapplethorpe had portrayed his African American lover-faceless and focused on their penis. The website asked its posters to classify their own penis size as S, M, L, or XL. About 80 percent of Africans said they were XL. The wider gay pornographic obsession with penis size to which Africans were responding was apparently 


\section{4 / Para-ethnography, Golf, and the Internet}

fairly recent, according to Waugh (1996, 324). It seems to have appeared only after the 1930s, after the invention of portable cameras and close-up lenses.

Profiles coupled two basic themes: African sexual superiority along with the desire for a long-term relationship, ideally marriage. Some profiles were quite short. "Dreaming to Be with You and Marry if Possible." "Really hope to find the right man in my life to spend the rest of my life with." "I am looking for a soulmate, the one who will care, love me and satisfy me." One had perhaps copied an African American Internet profile: "im a cuul cutie out here looking for relationship $n$ shit im very down to earth $n$ very cuul to hang out wif gooogle me niggas if yall wanna noe more."

Some were humorous: "I'm the male reproductive part of the flower." "Hi there. I am a hard master here seeking a slave to train hard who will pay every two weeks." "Am looking for an old man who is ready to meet me for a serious relationship." "I want you to get swept away. I want you to levitate. I want you to sing with rapture, dance like a dervish, because we give hot and crazy sex and hot fuck. Have you experienced sex in the jungle before?"

One young man presented himself as a master for European slaves in a particularly historically inventive way. In his profile, he pointed out that during colonial wars, when European soldiers were taken captive and held by African forces, they were raped. They were raped so expertly that the Europeans began to appreciate it. This illustrates, the profile claimed, why and how Africans make the best masters-a dramatic reversal, of course, of the actual realities of colonial conquest. 